\title{
Tudo Bem e o nacional-popular no Brasil dos anos 70
}

Tânia da Costa Garcia*

\section{Resumo:}

Dirigido e escrito por Arnaldo Jabor, Tudo bem foi veiculado nas salas de projeção no ano de 1978 - período de distensão da ditadura - com o apoio governamental da Embrafilme. O filme constitui referência documental para a análise do discurso do artista engajado, após o Golpe de 64, e a política cultural implementada pelos consecutivos governos militares. Tudo bem traz, já no título, uma ironia aos tempos vividos. A história transcorre no bairro de Copacabana, no Rio de Janeiro, num apartamento em reforma de uma família de classe média.

Palavras-chaves: cinema novo, nacional-popular e ditadura militar.

\section{$O$ cineasta engajado}

A maior parte da filmografia de Arnaldo Jabor está situada entre os anos da ditadura militar. Tem início em 1965, logo após o Golpe, com o curta O Circo. Seu primeiro longa-metragem é de 1967, Opinião Pública. Durante a década de 70, realizou Pindorama e adaptou para o cinema obras literárias de Nelson Rodrigues, como $O$ Casamento (1975) e Toda Nudez Será Castigada (1972) - premiado como melhor filme no Festival de Gramado. Após render uma boa bilheteria, o filme terminou sendo vítima da censura em 1973. Em 1978 roteirizou e dirigiu Tudo bem. Nos anos 1980 foi a vez de Eu te Amo (1981) e Eu Sei que Vou te Amar (1985), totalizando sete longas e um curta.

Jabor era militante de esquerda. Como muitos dos jovens artistas dos anos 1960, um cepecista, isto é, um artista revolucionário. Colaborou com o jornal $O$ Metropolitano, órgão oficial da União Metropolitana dos Estudantes do Rio de Janeiro, e editou a revista $O$ Movimento, uma publicação ligada à UNE. No cinema, começou trabalhando ao lado de cineastas como Cacá Diegues e Leon Hirszman, ambos com passagem pelo CPC (Centro Popular de Cultura).

Nos anos 1960, o cinema brasileiro congregou-se ao ideário político das esquerdas, tendência que se abateu também sobre a música e o teatro. Nesse período, o engajamento no campo artístico era a tônica dominante. Os chamados Centros Populares de Cultura da UNE, cuja redação do Manifesto data de 1962, defendiam que o papel do artista deveria ser o de luta contra a alienação. A conscientização, levada ao 
povo através da arte, seria a forma de romper com a dominação e com o subdesenvolvimento. O ponto de partida era, portanto, a cultura popular, apropriada de forma didático-pedagógica pelos intelectuais e artistas de esquerda. Tal apropriação visava, por um lado, fazer a crítica de dentro dos valores e comportamentos dos setores populares, desconstruindo crenças e atacando tradições, a fim "politizar as massas", trazê-las para a causa da revolução:

... tudo começa pela essência do povo ... essa essência só pode ser vivenciada pelo artista quando ele se defronta a fundo com o fato nu da posse do poder pela classe dirigente e a conseqüente privação de poder em que se encontra o povo enquanto massa dos governados pelos outros e para os outros. Se não se parte daí não se é nem revolucionário nem popular, porque revolucionar a sociedade é passar o poder ao povo. (Manifesto do CPC Apud Buarque de Holanda, 2004, p. 23)

Caberia à arte engajada ser popular, uma manifestação legítima do povo, e ao mesmo tempo emancipadora, revolucionária. O "artista revolucionário popular" era predominantemente o jovem estudante oriundo das camadas médias, inconformado com a situação política e social de seu país. Era preciso efetivar as mudanças necessárias na direção de uma sociedade mais justa, igualitária, socialista. O movimento cepecista, marcado pelo paternalismo, investia no doutrinamento das "massas". Em entrevista concedida à Heloisa Buarque de Holanda para seu livro Impressões e Viagens, Arnaldo Jabor comenta os tempos de engajamento: "a gente pensava que a fome era um caso de falta de informação; se o povo fosse bem informado, aconteceria a revolução, sem nos darmos conta da extrema complexidade do problema".

O CPC orientava seus filiados ao exercício de uma arte militante, a serviço da "transformação": o conteúdo deveria ser priorizado em detrimento da forma. A estética, "coisa de burguês", ficaria em segundo plano, o fundamental era converter o povo e para tanto era preciso "falar a sua língua", o que na prática se dava de modo imitativo, caricato. A imposição desta fórmula foi responsável por conflitos estéticos e ideológicos que marcaram a produção artística dos anos 1960 e 70 em todos os campos.

Precursores do Cinema Novo registraram passagem pelos Centros Populares de Cultura, alimentado seus filmes com a visão do nacional-popular, cara aos CPCs. Mas nem todos estiveram de acordo com as diretrizes impostas. Carlos Diegues foi um dos que abandonaram a sigla em busca de autonomia estética sem, no entanto, deixar de inserir em seus filmes temáticas referentes ao nacional popular.

Neste início dos anos 1960, a cultura popular foi reivindicada também como forma de resistência às transformações impostas pelo capitalismo - não ao progresso 
industrial propriamente, mas ao formato importado de novos valores e comportamentos. O intenso processo de urbanização vivido, desde os anos 1950, com a verticalização das cidades e o estabelecimento de uma sociedade de consumo, eram percebidos como a presença de um “outro ameaçador”, que terminaria por impor padrões culturais, fazendo submergir o que era "nosso". A arte engajada deveria fazer a defesa do nacional ante essa ocupação, cujo principal canal de penetração eram os meios de comunicação de massa e seus produtos - difusores de uma cultura alienígena representada pela música, pelo cinema e pela publicidade.

A época era marcada por acontecimentos como a Guerra Fria, a Revolução Cubana (1959) e o movimento dos não-alinhados decorrente do processo de descolonização da Ásia e da África. O socialismo assumia feições particulares no terceiro mundo - termo que surge justamente nesse período - demarcando um posicionamento independente da bipolaridade mundial.

Viajando pela Europa, em contato com as novas tendências políticas dos movimentos de esquerda, Glauber Rocha publicava, em 1965, o manifesto Uma estética da fome, definindo o que deveria ser o Cinema Novo. Referia-se à realidade social da América Latina - colonizada e miserável -, inserindo aí o Brasil e a precariedade do fazer do cineasta brasileiro. Embora em muitos aspectos seu cinema se aproximasse ideologicamente das convicções políticas dos cepecistas ${ }^{1}$, para Glauber Rocha o Cinema Novo deveria não só filmar a miséria, mas responder por uma estética da miséria. Daí a defesa de um cinema diferente capaz de demarcar a nossa identidade e fazer frente à indústria cinematográfica estrangeira, à cultura alienante imposta, sobretudo, pelo imperialismo norte-americano. Entretanto, o Golpe de 1964, afetaria radicalmente essa simbiose entre povo e artista. Como bem sinaliza Jean-Claude Bernardet:

\footnotetext{
... intelectuais e artistas são como que repentinamente devolvidos a sua classe, à classe média, vista como reacionária, retrograda, e como traidora devido a seu papel na preparação do golpe. ... É necessário esconjurar esse vínculo com a classe média. ... O cineasta exorciza a classe média e se fustiga por ser talvez um de seus membros (p. 57, 58).
}

Para Ismail Xavier, após o Golpe há uma "passagem do público ao privado como desdobramento da discussão política do Cinema Novo" (Xavier, 2003, p.323328). Entra em foco a "crise da família" como representação da "anatomia da decadência". A crítica social e as totalizações, caras aos cinemanovistas, é transplantada para a família de classe média ${ }^{2}$. De acordo com Ismail, Arnaldo Jabor, integrante da segunda geração do Cinema Novo, é quem primeiro sinaliza essa passagem do público 
ao privado. Em “O Cinema Novo lê Nelson Rodrigues” (ibidem, p. 225-265), Ismail afirma:

... Meu interesse aqui é focalizar essa retomada de Nelson Rodrigues que teve em Arnaldo Jabor sua figura-chave, momento em que, a partir de Toda Nudez Será Castigada (1972) e O Casamento (1975), esse cineasta encontrou um certo "tom de fala" ao colocar o país em cena, dado que teve sua síntese na alegoria de Tudo Bem, já sem tomar o escritor como ponto de partida. (ibidem, p. 286)

O olhar de Ismail para a cena busca fazer a costura entre o Brasil de Nelson e o de Jabor: a moral conservadora da classe média como metáfora do Brasil arcaico ante as transformações impostas pela modernidade capitalista.

Sem discordar do referido autor e incorporando suas reflexões, colocamos o problema em outros termos. Diferentemente dos dois filmes anteriores inspirados na obra de Nelson Rodrigues, Tudo Bem (1978) foi realizado num momento em que a política cultural do regime, implementada em 1975, buscava reatar relações com setores da esquerda. A intenção do governo de distensão do general Ernesto Geisel era retirar desse grupo o monopólio da produção cultural. Tal estratégia, aparentemente contraditória, objetivava cooptar artistas e intelectuais para a encampação de um discurso sobre o nacional oriundo do poder em detrimento do nacional-popular, caro aos "subversivos".

A Embrafilme acenava, então, para aqueles cineastas anteriormente preteridos pela política da empresa, convidando-os para o banquete sobre o nacional. Tudo bem, objeto de análise deste artigo, além de uma crítica severa às camadas médias, expõe a negociação empreendida, entre o cineasta e a política cultural do regime militar, em torno do simbólico nacional. O filme ainda revela a visão conflitante de "povo e revolução", vivenciada pela esquerda, pós-Golpe de 64. As diferentes representações do nacional e o do popular constituem a razão dessa abordagem.

\section{Arte e engajamento após o Golpe}

Após o Golpe de 64, o discurso nacionalista como militância de esquerda - o nacional-popular - era eliminado.

No campo econômico o regime militar vinha, no sentido oposto das bandeiras da esquerda, selar definitivamente a relação de dependência do Brasil com o capital estrangeiro. Se durante o governo de Juscelino Kubitscheck o nacional- 
desenvolvimentismo confundiu os isebianos que apostaram no viés nacionalista da proposta, isto é, na possibilidade de um capitalismo autônomo, com o golpe essa dúvida se dissipava por completo.

O nacionalismo, no entanto, seria vulgarmente utilizado pelos militares, tendo em vista justificar o golpe como defesa da soberania do país contra os "agentes" do comunismo soviético.

Uma vez no poder, os golpistas tomaram algumas medidas para coibir possíveis resistências à nova ordem instituída. Em 1967, eram promulgadas a nova Constituição, a Lei de Imprensa e a Lei de Segurança Nacional. E a partir de 1969 a censura era oficialmente imposta à sociedade. Sem política cultural definida, em 1966 era criado o INC (Instituto Nacional de Cinema), consolidando

\footnotetext{
um programa que concentrava no Estado a possibilidade de desenvolvimento industrial do cinema, visto ser um órgão legislador, de fomento e incentivo, fiscalizador, responsável pelo mercado externo e pelas atividades culturais. A ele se incorporaram o INCE (Instituto Nacional de Cinema e Educação), do Ministério da Educação e Cultura, e o Geicine (Grupo Executivo da Indústria Cinematográfica), do Ministério da Indústria e Comércio ... (Amancio, 2000, p. 21)
}

A criação do INC, se por um lado foi uma forma de exercício de controle sobre a produção cinematográfica, por outro terminou por instituir definitivamente uma política de incentivo ao cinema nacional, tão esperada pelos cineastas em outros governos. A ditadura militar passava, desse modo, a uma atuação mais diretiva no campo da cultura.

Em 1969, surgia com capital misto - majoritariamente público - a Empresa Brasileira de Filmes, a Embrafilme. Inicialmente, visava a distribuição de filmes brasileiros no exterior, com o objetivo de difundir uma imagem positiva de Brasil, mas logo tal intenção foi deixada de lado a favor de uma expansão mais agressiva do mercado nacional. ${ }^{3}$

A Embrafilme era criada pela junta militar de transição, que assumia o poder entre o afastamento do marechal Arthur da Costa e Silva e o início do governo do general Emílio Garrastazu Médici.

A Empresa deveria se constituir dentro das perspectivas mercadológicas e ser competente para abrir espaço para a consolidação do cinema nacional, daí sua atuação na distribuição. Não se tratava simplesmente de financiar a produção cinematográfica, mas de garantir o cinema como indústria. $\mathrm{O}$ objetivo comercial-industrial do negócio era tão valorizado ou mais que seu aspecto cultural, ao ponto de haver uma produção 
indiscriminada que veiculava filmes eróticos - as famosas pornochanchadas, com o selo da Embrafilme.

Com a criação da Embrafilme em 1969, o governo militar chamava para si uma tarefa até então vista como subversiva, ou seja, a defesa do nacional.

No entanto, somente durante o governo do general Ernesto Geisel seria implantado um plano de ação efetivo na área cultural ${ }^{4}$. Com uma crise econômica prevista - decorrente do esgotamento do plano econômico vigente e de uma crise mais ampla de nível internacional - outras formas de cooptação social seriam necessárias, para garantir o apoio da sociedade ao governo. A abertura política iniciava-se timidamente. O governo reconhecia a necessidade de reatar relações principalmente com os segmentos da sociedade que exerciam influência sobre a opinião pública. Entre eles estavam os intelectuais, artistas e jornalistas.

Em 1975, durante a gestão do ministro Ney Braga, era elaborado um documento sistematizando uma "Política Nacional de Cultura". A PNC visava retirar do controle das esquerdas a condução da produção cultural, percebida como instrumento de mobilização política da sociedade. Para tanto o governo deveria definir as diretrizes de sua ação.

A valorização da cultura brasileira era entendida pelo documento como condição para preservação da soberania nacional. Nesse sentido, os conteúdos alienígenas difundidos pelos meios de comunicação eram percebidos como agentes a serviço do estrangeiro. A fim de combatê-los era preciso ocupar esse espaço midiático com algo que fosse $n o s s o^{5}$.

O binômio povo/nação perdia seu caráter contestatório a favor de uma interpretação que enfatizava a diversidade cultural, retomando o discurso agregador do “cadinho de raças", representantes de uma identidade mestiça da nação (Ramos, 1983, p. 122).

A política cultural definida pelo governo Geisel, ao mesmo tempo em que acenava com um discurso nacionalista, em muitos aspectos próximo das ideologias de esquerda, deixava claro quais eram os limites do "nacional" encampado pelo Estado. O projeto teve forte repercussão entre os cinemanovistas que, desde a criação da Embrafilme, se sentiam preteridos pela postura comercial-industrial adotada pela empresa. De fato, era a esses setores mais recalcitrantes que a mensagem se dirigia, na intenção de cooptá-los. Entretanto, de acordo com as novas diretrizes, não deveria mais 
o cineasta intervir na realidade, mas simplesmente registrá-la, captar as imagens e apresentá-la ao público brasileiro como o simbólico da nação.

Apesar da interferência ideológica, o Estado não pretendia uma produção oficial. Seu dirigismo era até certo ponto limitado, desde que se evocasse o nacional como forma de resistência à cultura alienígena, destruidora de nossas raízes e corruptora de nossa soberania.

Muitos cineastas de esquerda aderiram à política cultural do Estado, negociando com o poder as imagens de nação inventadas pelo cinema. Isto é, se de um lado aparentemente se submetiam ao nacionalismo sem conflitos propagado pelo regime, excluindo um discurso mais contundente de oposição, por outro, nas brechas da censura, veiculavam - sobretudo durante o período de distensão - uma ampla crítica ao Brasil dos militares e àqueles setores da sociedade que haviam apoiado o Golpe.

Com a reestruturação da Embrafilme, tivemos no período 1974-1978 a chamada época de ouro do cinema nacional. Houve um aumento expressivo de capital derivado sobretudo da fusão com o INC e da obrigatoriedade de exibição de filmes nacionais girando em torno de 112 dias anuais. Tais medidas garantiram um retorno à Empresa financiadora, co-produtora e distribuidora destas películas (Amancio, 2000, p. 57).

$\mathrm{Na}$ filmografia de Arnaldo Jabor, Pindorama (1971) e Toda Nudez Será Castigada (1973) foram totalmente financiados pela Empresa Brasileira de Cinema, e $O$ Casamento (1975) foi somente distribuído. Enquanto Tudo Bem (1978), Eu te Amo (1981) e Eu Sei que Vou te Amar (1985) foram co-produzidos e distribuídos pela Embrafilme (ibidem, anexos p. 135-179). Portanto, podemos afirmar que a carreira de cineasta de Jabor esteve sempre atrelada às facilidades promovidas pelo Estado. Aliás, vale especular se seu último filme, datado de $1985^{6}$, e o encerramento de suas atividades como roteirista e diretor estariam relacionados à decadência da Embrafilme.

\section{O filme}

Uma família estereótipo das camadas médias, seus valores e comportamentos no Brasil dos anos 1970, é recortada no filme de Jabor como o segmento mais representativo da ideologia do regime militar. $\mathrm{O}$ golpe fora realizado pelas elites civis e militares com apoio desse setor intermediário, temeroso das ameaças do comunismo. Sob a ditadura o país conhecia o milagre econômico, o acesso ao consumo como solução para todos os males. 
A trama se desenvolve no espaço fechado de um apartamento em Copacabana. As personagens filiam-se a grupos e subgrupos que demarcam oposições: grupo 1, a família; grupo 2, as empregadas domésticas; grupo 3, os operários da construção civil.

O grupo familiar subdivide-se da seguinte forma: Juarez, o marido, funcionário público aposentado do IBGE e ex-militante integralista. Durante quase todo o filme, seu personagem traja hobby e chinelos como se da vida nada mais esperasse - os novos tempos não lhe interessam. Seu lugar dentro da casa é o escritório ou a biblioteca. Lá se encontram suas lembranças do passado, a memória nacional simbolizada por cânticos indígenas e aves empalhadas da fauna brasileira. Sua esposa, Elvira, é a típica mulher do mundo privado, sua preocupação fundamental é com a vida conjugal. Não dando crédito à impotência sexual do marido, apela para todo tipo de misticismo para afastar da vida dele a outra, a amante imaginária. É essa desconhecida que no subgrupo ocupa o lugar da mulher desejada em oposição à esposa santa e guardiã da moral. Os filhos do casal são dois. A filha segue o exemplo da mãe, sua preocupação fundamental é arranjar um casamento. O filho, ao contrário do pai, fervoroso nacionalista, trabalha numa empresa norte-americana - sinais dos tempos!

O grupo das domésticas subdivide-se na serviçal devota, vinda do norte, que no decorrer da trama torna-se milagreira, e na prostituta, sem fé, corrompida pelos vícios da metrópole.

E finalmente o terceiro grupo: os operários da construção civil. A subdivisão é demarcada por Piauí, migrante nordestino, inconformado com sua condição social.

A narrativa se desenvolve de forma linear: introdução, desenvolvimento e conclusão. A recorrência às alegorias, traço estético do Cinema Novo, não deixa dúvidas quanto à filiação do cineasta. Toda a história se desenrola no interior de um grande apartamento em Copacabana. A câmera de Jabor filma o teatro. Nesse recurso de aprisionar as cenas no interior do apartamento, muitas vezes o que se vê é uma espécie de cinema apoiado no palco italiano, cuja movimentação interna se dá nas chamadas três paredes - fundo e laterais -, não aproveitando a quarta parede - recurso muito usado na decupagem clássica.

\section{O povo emoldurado}

Juarez, embora imerso no mundo privado, em suas lembranças, é quem faz a ponte com o mundo externo. Na primeira seqüência ${ }^{7}$ redige uma carta-denúncia, 
provavelmente endereçada ao espaço do leitor de um jornal diário, contestando as altas abusivas do preço da carne. Compondo um plano médio de conjunto, a cena traz Juarez na penumbra do escritório, debruçado sobre a máquina de escrever, acompanhado ao fundo pela bandeira do Brasil e pelo retrato de Nossa Senhora fixados na parede. O simbólico da classe média - o nacionalismo de fachada e a moral cristã - é logo apresentado. Durante a redação todos os seus amigos do passado, fantasmas da sua memória, participam da cena: Alarico Sombra, veterinário e dentista, fundador do Clube Integralista de Vassouras e redator do jornal Camisa Verde; Jacometti, imigrante italiano, proprietário de uma indústria de massa; e por último o pediatra metido a poeta e conquistador.

Em meio aos seus devaneios e à redação da carta-denúncia, questiona Juarez: “30 anos de integridade, para quê?”

Jacometti completa: "É, para quê? Tive de vender minha fábrica para os americanos. Os galpões foram transformados em indústria de autopeças. É por isso, Juarez, que sou a favor de um capitalismo construtivo."

Juarez completa: "sem lucro".

Aqui a palavra-chave é integridade. Possui no excerto sentido duplo, fazendo a ponte entre o público e o privado. Solta na primeira frase, remete à vida pessoal do personagem: trinta anos de casamento, íntegro, cumpridor dos seus deveres, dobrandose aos valores e à moral da classe média. Integridade ainda sugere a filiação política de Juarez ao integralismo. "A idéia força central do Manifesto [Integralista] é, pois, indiscutivelmente, o nacionalismo cujo conteúdo é mais cultural que econômico" (Trindadem in Fausto, 1986. v. III, p. 322). Nesse aspecto como em outros - proteger o Brasil da luta de classes, o anticomunismo e o fim dos partidos políticos -, o integralismo se aproxima da ideologia nacionalista promovida pelos militares. A filiação política do personagem é o caminho encontrado por Jabor para driblar a censura e fazer a crítica ao regime.

Já para o imigrante italiano não poderia haver integridade num país onde a concorrência era desigual. $\mathrm{O}$ ex-industrial se sentia vítima do capitalismo estrangeiro. Como ser ao mesmo tempo nacionalista e estabelecer uma relação de dependência com a economia internacional?

Esta relação de oposição entre capitalismo subdesenvolvido (dependente) e nacionalismo era, no entanto, negada pelos militares que defendiam, no plano simbólico, uma realidade sem correspondência no plano econômico. 
Nesta mesma seqüência, encerrando a carta escrita ao jornal, o poeta parnasiano é chamado a dar um "fecho de ouro". Confundindo os direitos do cidadão com patriotismo, dita o final vibrante da missiva: "Escutem! O Brasil andando. São multidões que crescem de todos os lados. Não são barulhos nem do mar nem da floresta. Ouço milhões de passos andando, andando, andando e para onde?"

A visão do poeta descreve o Brasil presente: o nacional reivindicado pelo poder incluía o povo, mas um povo sem rumo, que não mais constituía ameaça. A relação da multidão com o mar e a floresta, relação de negação, mas também de associação, fixam a natureza e o povo como elementos representantes da nação.

Tal imagem definidora se confirma em outra seqüência quando Juarez, sentado em frente à televisão, assiste às imagens da pororoca, sob a locução magnetizante de Amaral Neto, o repórter - quem da geração dos 1970 não reconheceria a voz inconfundível do jornalista ou esqueceria das imagens angustiantes do fenômeno? A pororoca é descrita pelo locutor como um acontecimento fora do comum, fora do controle dos homens, mas em harmonia com a natureza. Esse era o Brasil exuberante dos militares.

Na quinta seqüência, no café da manhã, toda a família encontra-se reunida à mesa, menos o filho que, ao telefone, conversa em inglês sobre trabalho. Do lado de fora, pendurados em andaimes, dois pedreiros restauram a fachada do prédio. A câmera posicionada do lado de dentro do apartamento emoldura a cena aproveitando o enquadramento da janela. $\mathrm{O}$ mundo de dentro entra em contato com o de fora.

Sem compartilhar do mesmo espaço, um breve diálogo se estabelece entre Juarez e um dos homens sobre a possibilidade de reforma do seu apartamento. Em seguida um dos pedreiros narra para o outro um episódio do "mundo cão" ocorrido na favela onde mora: fome, roubo, briga e assassinato. O companheiro de andaime ouve atento, nada responde, emendando um samba. Enquanto a família ouve espantada as desgraças daquela realidade distante, Juarez estampa um olhar de contentamento e conclui: "Olha que grande povo: infantil, ignorante, mas capaz de criar beleza diante da miséria. São antes de tudo uns fortes."

O comentário do ex-integralista traz a imagem idealizada do povo como a alma da nação, citando Euclides da Cunha, crente "antes de tudo" no brasileiro e no progresso da República. A visão romântica de Juarez coincide com aquela proclamada pela política cultural dos governos militares: o povo compõe o simbólico da nação e, como 
tal, deve ser emoldurado, empalhado como as aves da fauna brasileira que adornam seu escritório.

Após o café, na cozinha do apartamento, Elvira gerencia o cotidiano da família. Outra assistente doméstica é contratada. A nova empregada, com referências falsas, ganhava a vida como prostituta. O povo entra pela porta dos fundos na vida da família do ex-integralista.

Nesta intensa relação entre o público e o privado, os diálogos entre as personagens dentro do espaço privado são carregados de sentido duplo. Como na seqüência em que a filha chega da rua de madrugada, bêbada e chorando porque perdeu o namorado para a amiga. A mãe ouve as lamúrias da moça, mas logo se desvia pensando nos seus problemas conjugais. Na penumbra da sala, surge ao fundo a imagem alegórica de uma santa enquanto a mãe tem delírios sexuais.

Jabor ataca a hipócrita moral cristã da classe média, que aprisiona o corpo, inibindo o desejo. De repente a filha grita, interrompendo o devaneio da mãe e indagando sobre o seu destino: "Mas só tem cafajeste neste país?" A mãe, perdida em suas fantasias, murmura: “Acho que uma plástica resolve." A pergunta da filha, "só tem cafajeste nesse país?", na medida em que vem entrecortada, uma frase solta entre os delírios da mãe, soa como um ataque direto ao público, ou aos representantes do poder público. A resposta desconexa da mãe, "uma plástica resolve", se não responde à pergunta da filha, desvela a maneira como os problemas do país são enfrentados pelos homens do poder. O sentido ambíguo empregado promove um deslocamento do espectador de dentro para fora e de fora para dentro da trama.

Se a filha segue o mesmo destino da mãe - a busca de um casamento e a constituição de uma família -, o filho possui valores absolutamente diversos do pai. Trabalha numa multinacional como relações-públicas. Sua função é zelar pela integridade, isto é, pela imagem da empresa no mundo dos negócios. Sem ele não adianta produção, pesquisa, produtividade, contabilidade.

Novamente o cineasta ironiza o mundo das aparências - tônica dominante da vida política, da economia e das relações sociais no Brasil dos coronéis e dos generais. Em seguida ataca a juventude dos anos 1970: o grande desafio é fazer carreira numa multinacional. O tom de deboche com que trata o assunto, ridicularizando os personagens engravatados que se divertem contando piadas tolas e se deslumbram com a condição de trabalhadores da Decler, revela seu desprezo pela nova geração, distante 
da juventude revolucionária à qual pertenceu. A nova ordem declara a subserviência econômica e, por tabela, cultural ao capital estrangeiro.

\section{Luta de classes sem revolução}

$\mathrm{O}$ ponto de virada do filme tem início com a reforma do apartamento. $\mathrm{O}$ mundo que estava do lado de fora - "o povo infantil, ignorante, mas capaz de criar beleza diante da miséria" - migra de vez para dentro do cotidiano da família. O espaço privado se transforma em microcosmo da nação, expondo fissuras e conflitos sociais.

A partir desse momento a trajetória política do cineasta - seu engajamento, sua frustração com o "povo revolucionário" e suas novas convicções - domina o enredo com maior ênfase. Não toma partido de um grupo ou de outro. Distanciado, faz a crítica não só da classe média que "boicotou a revolução", mas do povo, o povo alienado nos seus valores, na brutalidade do seu cotidiano. Jabor quer agredir. A provocação é a atuação política que restou após o golpe e a liberdade vigiada, mas também após a descrença dos intelectuais e artistas na mobilização popular.

A sala de visitas é o único cômodo da casa que sofre a reforma. É esse o espaço que ostenta o status da família. Cúmplice do golpe militar, detentora de um moralismo hipócrita, a classe média, preocupada com as aparências, vive de forma não correspondente com sua verdadeira condição econômica. Assim é o Brasil de Jabor em Tudo Bem. A invenção do real integra a cultura política da nação: interditado o acesso à modernidade, encena-se o progresso.

Hora do almoço. Os pedreiros sentados nos andaimes montados na sala abrem suas marmitas. A dona da casa se aproxima na intenção de se desculpar por não poder fornecer a refeição. Reclamando do custo de vida, iguala-se ao povo, eliminando a diferença: "A vida piorou. Lembra do Carnaval antigamente? Hoje este carnaval acabou."

Todos concordam com a piora da situação, mas quanto ao Carnaval, reage convicto o pedreiro: "Mas hoje tem Escola de Samba, madame!" O cineasta manda o seu recado: para o povo, se tem samba, tem festa, vai tudo bem.

Elvira dá continuidade ao seu discurso populista: “Agora vejam, por exemplo, a Igreja. O Vaticano com todo aquele ouro... é um escândalo." Ao acusar a Igreja de espoliadora, elege um outro inimigo comum.

E, concluindo seu discurso conciliador, exalta o povo e seu modus vivendi: 
Deve ser bom comer de marmita. Vida simples, ... a vida é maravilhosa. Vocês trabalham aqui, comem no local de trabalho, depois tomam esse trem, vão lá para o subúrbio, moram lá nas suas casinhas. Quando precisam de algum conserto, graças a deus já são operários, é só consertar o telhadinho, a biquinha. O povo é bom, é muito bom! É verdade que tem exceções como esses bandidos aí do morro. Mas eu acho o povo bom. Eu tenho uma amiga que diz para mim: "Cuidado, olha os pivetes, vão te assaltar. O ladrão..." Mas eu não acho não. Eu acho o povo muito, muito bom.

Elvira se assume como diferente, distante do cotidiano do pobre. Reconhece as fronteiras e oposições existentes, mas busca apaziguar as tensões e possíveis conflitos, afirmando insistentemente que não entende o povo como inimigo. O povo é bom. No entanto, o povo é bom lá: "lá no subúrbio", "lá na sua casinha". Com o povo tão próximo, dentro da sua casa, é preciso apagar as fronteiras, evitar a revolta e manter a ordem.

Entretanto, na hora do dinheiro não há nada que possa ocultar os interesses conflitantes. A seqüência tem início com uma discussão a respeito do valor desembolsado por Juarez (o dono da casa) e os custos do empreiteiro com os encargos da obra e o pagamento dos pedreiros. Os pedreiros, trepados nos andaimes, assistem atentos à negociação dos dois homens que ocupam o centro da cena. De um lado Juarez regateia o preço, ameaça parar tudo, afirmando que seu dinheiro acabou. De outro, o empreiteiro explica que com aqueles valores não tem como continuar e propõe demitir alguns dos trabalhadores. Tem início um alvoroço: entre os trabalhadores não há unidade, coesão, consciência de classe. Um quer que o outro seja despedido em seu lugar. A preocupação é salvar a própria pele. De repente, um deles propõe como solução despedir o empreiteiro, já que todos sabem fazer o serviço, não precisam dele e ainda podem baratear os custos.

Para o ex-cepecista o povo não é revolucionário, ao contrário, não possui consciência política alguma, sua lógica é a da sobrevivência. No entanto, na última hora, sugere coesão e nomeia o espoliador.

A reforma prossegue normalmente até que outro problema interrompe o cotidiano previsível da família. Um dos pedreiros da obra, Piauí, recebe ordem de despejo do lugar em que vive. Toda sua família - mulher, criança, bebê, pai e mãe encontra-se agora na sala de visita em reforma. A solução seria ir para debaixo de algum viaduto da cidade até conseguir outro lugar abrigo. Diante da mazela, num impulso de compaixão, Elvira toma as dores da família e ordena que todos fiquem ali mesmo, enquanto Piauí, autorizado a deixar o trabalho, sai à procura de um outro barraco. A 
alienada dona de casa lembra então da Funai (Fundação Nacional de Amparo ao Índio) e da Funabem (Fundação Nacional de Amparo e Bem-Estar do Menor). Jabor manda o recado: para a classe média, menor infrator, índio e pobre é tudo a mesma coisa, é povo, e povo é problema dos órgãos públicos.

Enquanto a solução não vem, a família de Piauí fica no apartamento. Em pouco tempo eles improvisam um acampamento onde comem e dormem. Os dias vão passando e o problema não se resolve. A pobreza instalada no meio da sala passa a incomodar. A situação torna-se insustentável. Então Juarez, mancomunado com o síndico, arma um plano para se livrar da miséria abjeta. É simulada uma “ordem de despejo" imposta pelo condomínio. Piauí e sua prole devem deixar o apartamento. Indignado com a hipocrisia da família, se sentindo injustiçado, o único homem do povo desse filme de Jabor com alguma "consciência de classe", segundo a ideologia marxista, resolve se manifestar:

\footnotetext{
Ô Dr., eu não pedi um vale ao senhor? Eu pedi o vale justamente para pagar o meu barraco e não ser despejado. Eu acreditei no senhor e o senhor não acreditou em mim. Eu fui pedir por eles, porque por mim estou acostumado a me lascar. Eu vou me incomodar com isso? Eu já comi até lagartixa no nordeste. Agora o senhor imagina o que é um ser humano comer lagartixa? E até gostei, e é bom! Além de outras coisas. Então fomos do Piauí a Goiás a pé para construir Brasília. O meu velho aqui trabalhou em Brasília, construiu Brasília.
}

Nesse momento, Piauí pega do bolso do pai um jornal velho, guardado como lembrança desse episódio da história do país do qual participou. A câmera faz um enquadramento em detalhe das fotos: um ônibus de migrantes cruzando a estrada, ao lado de outros que seguem a pé; abaixo, na mesma página, JK sorridente na companhia de outros políticos, provavelmente em alguma festa de inauguração na Capital Federal. Enquanto o olhar de Juarez passeia pelas imagens do jornal, a música dos índios do alto Xingu, trilha sonora do integralista, significa a cena. Terminado o depoimento do senhor Piauí, a família se retira ao som improvisado de um repente de despedida, cantado pelo anônimo homem que, ao lado de JK, construiu Brasília - diante da miséria, o povo é capaz de criar beleza. O cineasta mais uma vez ironiza a visão de povo, cara às representações do nacional, propagada pelo regime militar.

Duas gerações de uma mesma família dedicada à construção civil. O pai trabalhou na construção da nova capital federal, utopia do progresso no sertão do Brasil, promessa de um novo tempo que em nada alterou a vida dos que compartilharam do sonho. Daí o filho, que sem maior sorte, seguiu a mesma sina do pai. O destino de ambos é a realização da felicidade do outro. O cineasta engajado sai em defesa do povo 
oprimido e indaga que nacionalismo é este de símbolos e retóricas que em nada contribui para uma sociedade mais justa.

Após a partida da família de nordestinos, na mesma seqüência, uma alegoria: ao som dos cânticos indígenas, Juarez cruza a sala por um túnel escuro formado por mãos estendidas que, desesperadas, atritam com seu corpo. É o perigo da multidão. O malestar de Juarez é absoluto. A câmera se fixa no rosto angustiado do personagem. O velho integralista, assim como o governo militar, integra simbolicamente o povo à nação, cultuando seus usos e costumes, mas não se interessa pela sua feia realidade, quer o povo longe, confinado ao seu "habitat natural". O povo não tem lugar na modernidade idealizada.

\section{Dionísio}

Em Tudo Bem a paixão pela vida, o sexo, a festa (o carnaval) e a fé verdadeira pertencem ao povo. A seqüência tem início com um batuque na cozinha. No comando estão alguns dos operários e a doméstica prostituta. A canção é Mestre-sala dos Mares ${ }^{8}$. O cortejo deixa a área de serviços. Simulando um desfile de escola de samba com direito a porta-estandarte e mestre-sala, segue em direção ao cômodo em reforma. Invade a sala, ameaça a propriedade. Jabor num rompante cepecista transforma o povo em revolucionário. Mas logo a tensão criada se dissipa. No final da seqüência, um cano do banheiro estoura e todos, pai, mãe, filhos e empregados correm para tentar estancar a água, ao som do batuque e da cuíca. Novamente, o Carnaval elimina as fronteiras sociais, promovendo o ideal da nação indivisa.

Atendendo aos propósitos políticos do cineasta, a MPB e seu conteúdo crítico dos anos 1970 é mais uma vez evocada e posta na boca do povo. A seqüência tem início com a doméstica-prostituta nua, maquiando o rosto no espelho. Entra em cena a outra serviçal que a toma pelo braço e mesmo prevendo o destino arrisca perguntar: "Onde você vai?" A resposta vem na letra da canção de Belquior Como Nossos Pais". Enquanto se veste para ganhar a vida na rua, a empregada-prostituta canta e dança agressiva e sensualmente, atravessando a cozinha e quebrando o que encontra pela frente. No final da seqüência, já na porta da rua, termina a canção com uma paródia "Você fica na casa de madame, mas eu vou para a batalha defender o meu". Jabor quer subverter a ordem, provocar, apavorar a moral cristã da classe média. Sai em defesa do 
popular e reivindica sua cultura como subversiva. Seu universo marginal é revelado pelo cineasta como dionisíaco, ameaça imanente ao status quo.

Naquela noite, enquanto a outra ganha a vida na rua, a doméstica devota geme e chora em seu quarto. Alguém da família resolve socorrê-la, mas a crente não responde. O filho mais velho arromba a porta do aposento. A doméstica deixa o quarto com as mãos estendidas, as palmas perfuradas sangrando como as chagas de Cristo. Vai para a rua - única cena externa do filme -, circula brevemente pela vizinhança em meio à noite movimentada de Copacabana. Será ela a redimir os pecados do mundo? Sua fé, a toda prova, a transforma em milagreira. Os moradores do condomínio fazem fila para receber as graças da "santinha", até que Juarez, enraivecido com a ignorância, popular termina pondo fim à peregrinação. Em Tudo Bem a fé, o misticismo e a superstição integram a cultura nacional. O cineasta, ao mesmo tempo que retrata a religiosidade popular, critica a alienação decorrente do misticismo e ainda a contrapõe à religião oficial e ao poder da Igreja Católica, representada na figura de Juarez. Ninguém doma o povo. Nem a esquerda comunista, nem os católicos de direita.

\section{O povo fora da festa}

A reforma acaba. Os trabalhadores estão reunidos na sala fazendo um lanche, quando um deles acusa o outro de ter roubado a sua banana, em segundos tem início uma discussão que termina num bárbaro assassinato. Com uma marreta um dos homens arrebenta a cabeça do outro. O povo bom, rústico, ingênuo idealizado pela direita e pela esquerda é violento. Seus atos são impulsivos, inconseqüentes. O povo não possui "consciência de classe", luta entre si. Mata aquele que, de acordo com a cartilha do socialismo científico, deveria ser seu companheiro na luta pela emancipação da miséria.

$\mathrm{Na}$ última seqüência, tem lugar a festa. Não conseguindo a tempo um transporte funerário para carregar o morto, a família resolve escondê-lo nas dependências da empregada. A crente passa a noite da festa velando o defunto, entoando ladainhas. $\mathrm{O}$ mais importante é a recepção, é receber os convidados e o norte-americano executivo da multinacional, agora também noivo da filha. No tapete da sala, o sangue e a carne da vítima. É preciso esconder, ocultar o sinal de que algo está fora do lugar. Ao som de Besame Mucho da orquestra de Ray Connif, os convidados e a família de Juarez se deslumbram boquiabertos com as explicações do ianque sobre a revolução tecnológica promovida pelo satélite, capaz de integrar, via meios de comunicação, o imenso 
território nacional e inserir, virtualmente, o Brasil na modernidade. Jabor delata: por trás do discurso nacionalista, a subserviência ao capitalismo estrangeiro, ao imperialismo norte-americano.

Na última seqüência, imagens aéreas das águas abundantes de Foz do Iguaçu. As imagens exuberantes da natureza se reportam mais uma vez ao ufanismo dos militares.

Se os cinemanovistas foram, de início, rebeldes ao controle exercido pelo Estado, primeiro via INC, depois pela Embrafilme, posteriormente, após a reformulação da Empresa Brasileira de Cinema, se deixaram seduzir pelas facilidades de financiamento, co-produção e distribuição promovidas. O adestramento do nacionalpopular, bandeira das esquerdas, constituiu o alvo da política cultural praticada pelo governo militar. A reação possível foi ambígua, no entanto, suficiente para demarcar fronteiras entre o discurso oficial e o posicionamento político de alguns cineastas.

Em Tudo Bem o discurso das esquerdas sobre o nacional atravessa o enredo e disputa espaço com a versão promovida pela ideologia do governo militar - é preciso driblar a censura. Não é mais o nacional-popular dos tempos do CPC - a descrença na revolução após o desmantelamento da luta armada promovido pela violência do regime militar, resultou num balanço crítico da ideologia e de todo o movimento de esquerda. Negociar, nas brechas da censura, as representações do nacional inventadas pela política cultural dos militares, constituiu, entretanto, uma forma de resistência contra o uníssono orquestrado pelo poder a fim de construir uma unidade de Brasil a despeito de todas as mazelas sociais.

Em nenhum momento pretendeu-se aqui uma análise das transformações sofridas pelo Cinema Novo em decorrência dos fatos políticos que marcaram os anos 1960 e os 70, ou a discussão dos desdobramentos da linguagem desta cinematografia nestas duas décadas. A trajetória de Jabor do CPC a Tudo Bem nos chama a atenção para as diferentes apropriações do nacional-popular como bandeira de luta das forças em conflito que nos anos 1960 disputavam um Brasil imaginado.

\section{REFERÊNCIAS BIBLIOGRÁFICAS:}

AMANCIO, T. Artes e manhas da Embrafilme. Cinema estatal brasileiro em sua época de ouro (1977-1981). Niterói, RJ. Editora da Universidade Federal Fluminense, 2000. BERNARDET, J. C. Cineastas e imagens do povo. São Paulo: Brasiliense, 1985. 
RAMOS, J. M. O. Cinema, Estado e lutas culturais nos anos 50, 60, 70. Rio de Janeiro: Paz e Terra, 1983.

TRINDADEM, H. Integralismo: teoria e praxis política nos anos 30. In: FAUSTO, B. História Geral da Civilização Brasileira. O Brasil Repúblicano: sociedade e política. São Paulo: Difel, 1986. v. III.

XAVIER, I. O Cinema Novo lê Nelson Rodrigues. In: O Olhar e a Cena: Melodrama, Hollywood, Cinema Novo e Nelson Rodrigues. São Paulo: Cosac e Naify, 2003.

GARCIA, Tânia da Costa. Tudo Bem and nacional-popular in Brazil of the 70's. História, São Paulo, v. 26, n. 2, p. 182-200, 2007.

\begin{abstract}
The film Tudo bem written and directed by Arnaldo Jabor, was released at the movie theaters in 1978 - during the dictatorial regime distention with Embrafilme governmental support. The film itself is a documental reference to the analysis of the political active artists'speech after the military empowerment in 1964, and the cultural policy established by the subsequent military governments. Tudo bem brings, in its own title, an irony to that time. The story has its place in Copacabana, in Rio de Janeiro, inside a mid-class apartment that was being repaired.
\end{abstract}

Keywords: cinema novo, national/popular, military dictature

Artigo recebido em 10/2007. Aprovado em 12/2007.

\title{
NOTAS:
}

\footnotetext{
* Professora do Departamento de História da UNESP, campus de Franca.

${ }^{1}$ Muitos dos cineastas do Cinema Novo iniciaram seu trabalho dentro das fileiras dos CPCs, entretanto o sectarismo impostos - a realização de uma arte didático-pedagógica - fez com que diversos artistas abandonassem o grupo em busca de liberdade para suas idéias. Tal fato, contudo, não os impediu de continuar incluindo em seus filmes temáticas caras aos cepecistas, como o nacional-popular e o antiimperialismo.

${ }^{2}$ De acordo com Bernardet a crítica à classe média, seus valores e seus costumes, surge quando o discurso sobre o povo revolucionário e a identificação do cineasta com seu universo é interrompida pelo Golpe de 64. Intelectuais e artistas, devolvidos à sua classe de origem, não perdoam o papel reacionário desse setor ao apoiar o golpe. Os ataques impiedosos ao comportamento recalcado e a postura conservadora da classe média são a resposta possível ao drama do pertencimento. Para Bernardet, diferentemente de Ismail, não se trata somente de uma estratégia política para driblar a censura (Bernardet, 1985. p. 56-58).

${ }^{3}$ É válido ressaltar que a verba administrada pela Embrafilme advinha do imposto recolhido sobre $40 \%$ da renda da remessa de lucro das companhias distribuidoras internacionais. (Lei de Remessas de Lucro de setembro de 1962) (Amancio, 2000, p. 21).

${ }^{4}$ Em 1973, durante o governo do presidente Médici, com Jarbas Passarinho como ministro da Educação e Cultura, teve circulação breve um documento que divulgava as "Diretrizes para uma política Nacional de Cultura".
} 


\footnotetext{
${ }^{5}$ A integração nacional via meios de comunicação foi, sem dúvida, uma das maiores preocupações dos governos militares - a Embratel criada em 1962 passava a operar a partir de 1967; em 1969 era inaugurada a transmissão via satélite. Na década de 1970 a televisão seria o principal agente propagador da ideologia do regime.

${ }^{6}$ Em 1990, numa co-produção franco-italiana, Jabor realizou Amor a primeira vista - um filme para TV, não veiculado no Brasil.

7 Antecedendo a apresentação dos créditos é introduzido o personagem: a imagem de Juarez na madrugada, na escuridão da sua sala, quase adormecido em frente ao aparelho de TV. A cena é cortada, dando lugar aos créditos que são projetados sobre a imagem de um velho filme caseiro, possivelmente da família de Jabor. As imagens são interligadas pela cântico indígena do Alto Xingu, trilha sonora predileta de Juarez. Jabor admite de saída seu pertencimento à classe média.

${ }^{8}$ A música de autoria de João Bosco e Aldir Blanc, Mestre sala dos mares, havia, na ocasião do seu lançamento, 1974, sido vítima da censura.

${ }^{9}$ Música de Belchior gravada em 1976.
} 